William M. Splinter MD FRCPC,

Michael R.N. Baxter MB FRCA,

H. Marion Gould MD FRCPC, Leslie E. Hall MD FRCPC,

Helen B. MacNeill MD FRCPC,

David J. Roberts MD FRCPC, Lydia Komocar RN

\title{
Oral ondansetron decreases vomiting after tonsillectomy in children
}

Vomiting is a common, unpleasant aftermath of tonsillectomy in children. Intraoperative intravenous ondansetron (OND) reduces vomiting after this operation. Our double-blind, placebocontrolled, randomized investigation studied the effect of the oral form of OND on vomiting after outpatient tonsillectomy in children. We studied 233 healthy children age 2-14 yr undergoing elective tonsillectomy. Subjects were given placebo (PLAC) or OND $0.1 \mathrm{mg} \cdot \mathrm{kg}^{-1}$ rounded off to the nearest 2 $\mathrm{mg}$ one hr before surgery. Anaesthesia was induced with either propofol or halothane $/ \mathrm{N}_{2} \mathrm{O}$. Vecuronium $0.1 \mathrm{mg} \cdot \mathrm{kg}^{-1}$ was administered at the discretion of the anaesthetist. Anaesthesia was maintained with halothane $/ \mathrm{N}_{2} \mathrm{O}, 50 \mu \mathrm{g} \cdot \mathrm{kg}^{-1}$ midazolam iv and $1-1.5 \mathrm{mg} \cdot \mathrm{kg}^{-1}$ codeine im. At the end of surgery, residual neuromuscular blockade was reversed with neostigmine and atropine. All episodes of in-hospital emesis were recorded by nursing staff. Rescue antiemetics in the hospital were $I$ $\mathrm{mg} \cdot \mathrm{kg}^{-1}$ dimenhydrinate iv for vomiting $\times 2$ and $50 \mu \mathrm{g} \cdot \mathrm{kg}^{-1}$ droperidol iv for vomiting $\times 4$. Parents kept a diary of emesis after discharge. Postoperative pain was treated with morphine, codeine and/or acetaminophen. The two groups were similar with respect to demographic data, induction technique and anaesthesia time. Oral OND $(n=109)$ reduced postoperative emesis from $54 \%$ to $39 \%, P<0.05$. This effect was most dramatic in-hospital, where $10 \%$ of the OND-patients and $30 \%$ of the PLAC-group vomited, $P<0.05$. The OND-subjects required fewer rescue antiemetics, $7 \%$ vs $17 \%, P<0.05$. In conclusion, oral ondansetron decreased the incidence of vomiting after outpatient tonsillectomy in children.

\section{Key words}

ANAESTHESIA: paediatric, outpatient;

SURGERY: tonsillectomy;

VOMITING: postoperative, ondansetron.

From the Department of Anaesthesia, Children's Hospital of Eastern Ontario, University of Ottawa, Ottawa, Ontario, Canada, K1H 8L1.

Address correspondence to: Dr. William Splinter, Department of Anaesthesia, Children's Hospital of Eastern Ontario, 401 Smyth Rd., Ottawa, Canada, K1H 8L1. Accepted for publication 27th November, 1994.
Chez l'enfant, les vomissements constituent un contrecoup désagréable de l'amygdalectomie. L'administration intraveineuse peropératoire d'ondansetron (OND) réduit l'incidence des vomissements après cette intervention. Notre recherche randomisée, à double aveugle et contrôlée avec placebo sintéresse à lïnfluence de la forme orale d'OND sur les vomissements après une amygdalectomie en ambulatoire chez les enfants. Notre étude inclut 233 enfants bien portants âgés de $2 \dot{a} 14$ ans programmés pour amygdalectomie. Une heure avant la chirurgie, les sujets reçoivent soit un placebo (PLAC) soit de l'OND 0,1 $\mathrm{mg} \cdot \mathrm{kg}^{-1}$ à la dose arrondie la plus proche de $2 \mathrm{mg}$. L'anesthésie est induite avec du propofol ou de lhalothane $/ \mathrm{N}_{2} \mathrm{O} . \mathrm{Du}$ vécuronium $0,1 \mathrm{mg} \cdot \mathrm{kg}^{-1}$ est adminstré à la discrétion de l'anesthésiste. L'anesthésie est entretenue avec halothane $/ \mathrm{N}_{2} \mathrm{O}$, midazolam $50 \mu \mathrm{g} \cdot \mathrm{kg}^{-1}$ iv et codéine $1-1,5 \mathrm{mg} \cdot \mathrm{kg}^{-1} \mathrm{im}$. A la fin de chirurgie, la curarisation est renversée avec de l'atropine et de la néostigmine. Tous les épisodes de vomissements sont compilés par le personnel infirmier. A lhopital, les antiémétiques de sauvetages sont le dimenhydrinate $1 \mathrm{mg} \cdot \mathrm{kg}^{-1}$ iv pour les vomissements $\times 2$ et dropéridol $50 \mu \mathrm{g} \cdot \mathrm{kg}^{-1}$ iv pour les vomissements $\times 4$. Les parents notent les vomissements après le congé. Les deux groupes sont comparables au regard des données démographiques, de la technique d'induction et de la durée de l'anesthésie. L'OND oral diminue lincidence des vomissements de $54 \%$ à $39 \%, P<0,05$. Cet effet est surtout dramatique à lhôpital où $10 \%$ des patients du groupe OND vomissent comparativement à $30 \%, P<0,05$. le groupe OND a moins besoin d'antiémétiques de sauvetage, $7 \%$ vs $17 \%, P$ $<0,05$. En conclusion, l'ondansetron oral diminue lincidence des vomissements postamygdalectomie en chirurgie ambulatoire chez l'enfant.

Vomiting is a frequent, unpleasant consequence of general anaesthesia in children. ${ }^{1}$ Persistent vomiting may result in dehydration and metabolic derangements. Furthermore, it may raise costs to the Health Care System by delaying discharge from day care surgical units (DCSU) or unscheduled hospital admissions.

Pandit $^{2}$ reported a $75 \%$ incidence of vomiting after tonsillectomy in children. The aetiology of this vomiting is multifactorial and is probably controlled through the 
chemoreceptor trigger zone (CRTZ) in the medulla. Effective antiemetic agents block neurotransmitters found within the CRTZ. ${ }^{3}$ Agents known to block dopamine $\left(D_{2}\right)$, histamine $\left(\mathrm{H}_{1}\right)$, and muscarinic cholinergic receptors have antiemetic effects. Recently, antagonists of 5hydroxytryptamine type $3\left(5-\mathrm{HT}_{3}\right)$ receptors have been noted to have antiemetic properties. The first commercially available drug of this class is ondansetron. Ondansetron given $\dot{i}$ reduces vomiting after surgery. ${ }^{4-6} \mathrm{Un}$ fortunately, the $i v$ form of the drug is expensive. However, oral ondansetron is available at two-thirds of the price of the parenteral form and is effective in adults. ${ }^{\text {? }}$

The purpose of this double-blind, placebo-controlled, randomized study was to determine the effect of oral ondansetron on vomiting after outpatient paediatric tonsillectomy.

\section{Methods}

Following hospital ethics committee approval and written parental consent, we studied 233 healthy children age 2-14 yr scheduled to undergo elective tonsillectomy or adenotonsillectomy. Subjects were excluded if they had a study-drug allergy or they were unwilling to ingest the medication. Patients were given placebo or ondansetron $0.1 \mathrm{mg} \cdot \mathrm{kg}^{-1}$ rounded off to the nearest $2 \mathrm{mg}$ in a doubleblind randomized fashion po one hr before surgery with a sip of water.

After placement of routine monitors, anaesthesia was induced with halothane $/ \mathrm{N}_{2} \mathrm{O}$ or $2.5 \mathrm{mg} \cdot \mathrm{kg}^{-1}$ propofol mixed with $0.5 \mathrm{mg} \cdot \mathrm{kg}^{-1}$ lidocaine. Vecuronium 0.1 $\mathrm{mg} \cdot \mathrm{kg}^{-1}$ was administered to facilitate tracheal intubation at the discretion of the individual anaesthetist. Anaesthesia was maintained with halothane $/ \mathrm{N}_{2} \mathrm{O}, 50 \mu \mathrm{g} \cdot \mathrm{kg}^{-1}$ midazolam $i v$ and $1-1.5 \mathrm{mg} \cdot \mathrm{kg}^{-1}$ codeine im. At the conclusion of surgery, residual neuromuscular blockade was reversed with $20 \mu \mathrm{g} \cdot \mathrm{kg}^{-1}$ atropine and $60 \mu \mathrm{g} \cdot \mathrm{kg}^{-1}$ neostigmine. Orogastric tubes were not used during this study. Postoperatively, patients were offered clear fluids in the DCSU only if the child requested a drink. All episodes of in-hospital emesis were recorded by nursing staff. Parents kept a diary of emesis after discharge. Postdischarge vomiting was double-checked on the day after surgery, when the parents were contacted by a research assistant and reminded to mail their diary. Rescue antiemetics in the hospital were $1 \mathrm{mg} \cdot \mathrm{kg}^{-1}$ dimenhydrinate $\dot{\nu}$ for vomiting $\times 2$ and droperidol $50 \mu \mathrm{g} \cdot \mathrm{kg}^{-1}$ for vomiting $\times 4$. Postoperative pain was treated with morphine, codeine and acetaminophen. Patients were discharged from our DCSU if after a minimal four-hour stay they were not nauseated, had little or no pain, were ambulatory and were not actively bleeding.

Data were compared with one-way ANOVA, Chisquare analysis and Fisher's Exact Test. For sample size determination and significance testing, the accepted alpha and beta errors were 0.05 and 0.20 , respectively. The predicted incidence of vomiting was $40 \%$ in the placebo group and $25 \%$ in the ondansetron groups.

\section{Results}

Six patients, three in each group, underwent adenoidectomy only. These patients were included in the analysis. The groups were similar with respect to demographic data, anaesthesia time and intraoperative blood loss (Table 1). The study medication was administered $72 \pm$ 29 min, mean $\pm S D$, before surgery. Sixty-eight patients underwent $i$ induction, of whom 32 received placebo and 36 ondansetron.

In-hospital pain management was almost identical. Fourteen patients in each group received morphine in the post-anaesthetic recovery room (PAR). Before discharge from hospital codeine $1 \mathrm{mg} \cdot \mathrm{kg}^{-1}$ was given po or $i m$ to $79 \%$ of the patients in both groups.

Patients vomited from 0-14 times during the $24 \mathrm{hr}$ after surgery (Figure) with a reduced incidence of emesis among the oral ondansetron patients (Table II). This was especially true in hospital, wherein only $10 \%$ of the ondansetron group vomited. Further, the placebo group had 12 and 53 more emetic spells in the PAR and DCSU, respectively, than did the ondansetron group, $P<0.05$. Rescue antiemetics were required less often by the ondansetron-treated patients (Table II). Four patients, all in the placebo group, required a second rescue antiemetic, droperidol. One patient in each group was admitted after surgery because of vomiting. Also, one patient in each group returned to hospital the day after surgery because of emesis. The incidence of vomiting was not affected by induction technique with emesis rates of $45 \%$ and $51 \%$ in children whose anaesthesia was induced by $i v$ and inhalation, respectively.

\section{Discussion}

The present study investigated a new therapeutic approach for the prevention of vomiting after paediatric tonsillectomy. A single, oral, preoperative dose of ondansetron decreased the incidence of vomiting during the first four hours after outpatient tonsillectomy in children, but there was no difference in the incidence of vomiting after discharge from hospital.

Other investigators have studied the effect of antiemetics on vomiting after tonsillectomy. The incidence of vomiting observed in this study is comparable with the $12-75 \%$ previously noted. 2,8

Could the $39 \%$ vomiting rate in the treatment group be improved? The dose of ondansetron is based on Dupeytron's ${ }^{7}$ adult study and a paediatric study in which the weight-normalized clearance and volume of distri- 
TABLE I Patient characteristics

\begin{tabular}{llllllll}
\hline Group & $n$ & $\begin{array}{l}\text { Age } \\
(y \mathrm{r})\end{array}$ & $\begin{array}{l}\text { Weight } \\
(\mathrm{kg})\end{array}$ & $\begin{array}{l}\text { EBL } \\
(\mathrm{mL})\end{array}$ & $\begin{array}{l}\text { Anaes. time } \\
(\mathrm{min})\end{array}$ & $\begin{array}{l}\text { PAR time } \\
(\mathrm{min})\end{array}$ & $\begin{array}{l}\text { DCSU time } \\
(\mathrm{hr})\end{array}$ \\
\hline $\mathrm{P}$ & 124 & $6.6 \pm 2.9$ & $26 \pm 14$ & $37 \pm 25$ & $36 \pm 12$ & $47 \pm 11$ \\
$\mathrm{O}$ & 109 & $7.1 \pm 2.7$ & $27 \pm 10$ & $37 \pm 25$ & $37 \pm 18$ & $45 \pm 10$ & $3.9 \pm 0.7$ \\
\hline
\end{tabular}

Mean $\pm \mathrm{SD}, \mathrm{P}=$ placebo, $\mathrm{O}=$ ondansetron, $\mathrm{EBL}=$ estimated intraoperative blood loss, $\mathrm{PAR}=$ post-anaesthetic recovery room, $\mathrm{DCSU}=$ daycare surgical unit.

TABLE 11 Vomiting incidence

\begin{tabular}{|c|c|c|c|c|c|c|}
\hline \multirow[b]{2}{*}{ Group } & \multirow{2}{*}{$\begin{array}{l}\text { Vomit } \\
\%\end{array}$} & \multicolumn{4}{|c|}{ Vomit by location $\%$} & \multirow{2}{*}{$\begin{array}{l}\text { Rescue Meds. } \\
\%\end{array}$} \\
\hline & & $P A R$ & $D C S U$ & Day $i$ & Day 2 & \\
\hline$P$ & $54^{*}$ & $5^{*}$ & $29 *$ & 33 & 17 & $17^{*}$ \\
\hline 0 & 39 & nil & 10 & 32 & 19 & 7 \\
\hline
\end{tabular}

$\mathrm{P}=$ placebo, $\mathrm{O}=$ ondansetron, ${ }^{*} P<0.05$, Chi-square or Fisher's Exact Test.

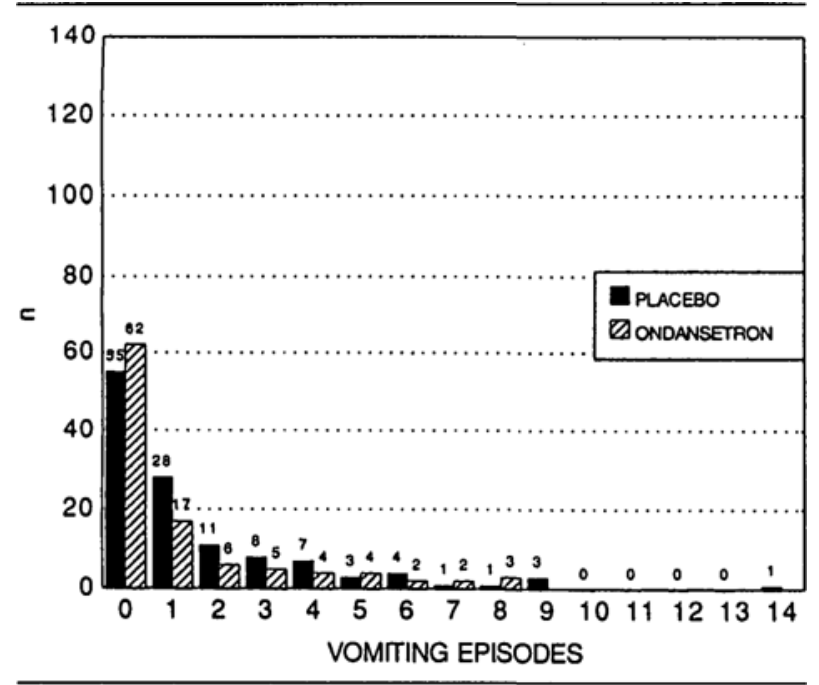

FIGURE The distribution of patients with 0-14 emetic episodes among the two groups.

bution of ondansetron in children aged 3-12 yr were similar to that in adults. ${ }^{9}$ Subsequently, Rust and Cohen ${ }^{9}$ observed a progressive decrease in postoperative vomiting among adults after an increase of a single oral dose of ondansetron from 0 to 4 to 8 to $16 \mathrm{mg}$ (approximately $0-0.2 \mathrm{mg} \cdot \mathrm{kg}^{-1}$ ). Thus, an oral dose of $0.2 \mathrm{mg} \cdot \mathrm{kg}^{-1}$ of ondansetron should have a greater effect ${ }^{10}$ than the $0.1 \mathrm{mg} \cdot \mathrm{kg}^{-1}$ used in our study. Alternatively, Litman ${ }^{4}$ used ondansetron $0.15 \mathrm{mg} \cdot \mathrm{kg}^{-1} i v$ during paediatric tonsillectomy and noted a decrease in the frequency of vomiting from the control's $73 \%$ to $23 \%$. Another option to extend the effect of ondansetron after discharge would be to repeat the oral dose immediately before release from hospital or by the use of a longer-acting $5-\mathrm{HT}_{3}$ antagonist.
Finally, an additional antiemetic may further decrease vomiting after tonsillectomy.

There were several problems with our study. Because the pharmacokinetic and pharmacodynamic behaviour of oral ondansetron have not been studied in the paediatric population, much of the study design was based on adult data. From a practical perspective, not all children will ingest oral medication, nor will they all arrive at least one hour before surgery to allow adequate absorption prior to anaesthesia. Finally, the study population included patients undergoing tonsillectomy and adenotonsillectomy (T\&A). Theoretically, the T\&A patients should bleed more postoperatively and have a greater incidence of emesis secondary to greater ingestion of blood in the postoperative period. There was not an observed increase in emesis in the T\&A subgroup during the current study.

In summary, the current investigation demonstrated that a single dose of $0.1 \mathrm{mg} \cdot \mathrm{kg}^{-1}$ ondansetron gives po one hour before tonsillectomy in children decreased postoperative vomiting, particularly during the first four hours.

\section{Acknowledgements}

We thank our colleagues in Otolaryngology and Nursing for their cooperation and advice during this study. We also wish to thank Ms. Nancy Bye-Carson and Ms. Tina Subissati for their vital help in conducting this investigation.

\section{References}

1 Cohen MM, Cameron CB, Duncan PG. Pediatric anesthesia morbidity and mortality in the perioperative period. Anesth Analg 1990; 70: 160-7.

2 Pandit U, Pryn S, Randel G, Levy L, Lewis I. Nitrous oxide does not increase postoperative nausea/vomiting in 
pediatric outpatients undergoing tonsillectomyadenoidectomy. Anesthesiology 1990; 73: A1245.

3 Peroutka SJ, Snyder SH. Antiemetics: neurotransmitter receptor binding predicts therepeutic actions. Lancet 1982; 1: 658-9.

4 Litman RS, Wu CL, Catanzaro FA. Ondansetron decreases emesis after tonsillectomy in children. Anesth Analg 1994; 78: 478-81.

5 Kovac A, McKenzie R, O'Connor T, et al. Prophylactic intravenous ondansetron in female outpatients undergoing gynaecological surgery: a multicentre dose-comparison study. Eur J Anaesthesiol 1992; 9 (suppl 6): 37-47.

6 Rose JB, Martin TM, Corddry DH, Zagnoev M, Kettrick $R G$. Ondansetron reduces the incidence and severity of poststrabismus repair vomiting in children. Anesth Analg 1994; 79: 486-9.

7 Dupeyron JP, Conseiller C, Levarlet $M$, et al. The effect of oral ondansetron in the prevention of postoperative nausea and vomiting after major gynaecological surgery performed under general anaesthesia. Anaesthesia 1993; 48: 214-8.

8 Grunwald Z, Guarnieri K, Torjmann $M$. Comparison of the antiemetic effect of IV droperidol given in the PACU versus a double dose regimen in children having tonsillectomy and adenoidectomy. Anesth Analg 1992; 74: S124.

9 Lerman J, Spahr-Schopfer IA, Sikich N. Pharmacokinetics of intravenous ondansetron (5- $\mathrm{HT}_{3} \mathrm{An}$ tagonist) in healthy children. Can J Anaesth 1993; 40: A24.

10 Rust $M$, Cohen LA. Single oral dose ondansetron in the prevention of postoperative nausea and emesis. Anaesthesia 1994; 49 (Suppl): 16-23. 